\title{
Student Behaviors and Interactions Influence Group Discussions in an Introductory Biology Lab Setting
}

\section{Alex R. Paine and Jennifer K. Knight*}

Department of Molecular Cellular and Developmental Biology, University of Colorado Boulder, Boulder, CO 80309-0347

\begin{abstract}
Past research on group work has primarily focused on promoting change through implementation of interventions designed to increase performance. Recently, however, education researchers have called for more descriptive analyses of group interactions. Through detailed qualitative analysis of recorded discussions, we studied the natural interactions of students during group work in the context of a biology laboratory course. We analyzed multiple interactions of 30 different groups as well as data from each of the 91 individual participants to characterize the ways students engage in discussion and how group dynamics promote or prevent meaningful discussion. Using a set of codes describing 15 unique behaviors, we determined that the most common behavior seen in student dialogue was analyzing data, followed by recalling information and repeating ideas. We also classified students into one of 10 different roles for each discussion, determined by their most common behaviors. We found that, although students cooperated with one another by exchanging information, they less frequently fully collaborated to explain their conclusions through the exchange of reasoning. Within this context, these findings show that students working in groups generally choose specific roles during discussions and focus on data analysis rather than constructing logical reasoning chains to explain their conclusions.
\end{abstract}

\section{INTRODUCTION}

Environments that allow for learning are naturally social in nature. According to social cognitive theory, learning occurs in and cannot be separated from a social context (Bandura, 1977; Vygotsky, 1978). Furthermore, within social learning contexts, the ways students engage with one another can impact whether they are able to generate conceptual explanations for and derive meaning from the content they learn (Chi, 2009). Ultimately, when students work together in groups, grapple with different interpretations of data, and construct conclusions or models collaboratively, their learning is deeper. Historically, these collaborative interactions have been called "argumentation," a method of reasoning in which consensus about a claim is reached through using evidence to explain a rationale for drawing a conclusion (Toulmin, 1958; Erduran et al., 2004, Osborne, 2010). When instructors encourage collaborative practices that lead to argumentation, students can learn to engage in critical thinking, problem-solving, and scientific communication, through which they develop better understanding of scientific concepts (Cavallo, 1996; Cavallo et al., 2004; Johnson and Lawson, 1998; Berland and Reiser, 2009; National Research Council [NRC], 2012) and their ability to use logical and scientific reasoning (NRC, 2007; American Association for the Advancement of Science [AAAS], 2011). However, there is also evidence that students generally do not choose to exchange reasoning during in-class discussions without prompting or training (Zohar and Nemet, 2002; Lubben, 2009; Knight et al., 2013, 2015).
Grant Ean Gardner, Monitoring Editor Submitted Mar 24, 2020; Revised Sep 17, 2020; Accepted Sep 25, 2020

CBE Life Sci Educ December 1, 2020 19:ar58 DOI:10.1187/cbe.20-03-0054

*Address correspondence to: Jennifer K. Knight (Jennifer.Knight@colorado.edu).

() 2020 A. R. Paine and J. K. Knight. CBE-Life Sciences Education (๑) 2020 The American Society for Cell Biology. This article is distributed by The American Society for Cell Biology under license from the author(s). It is available to the public under an Attribution-NoncommercialShare Alike 3.0 Unported Creative Commons License (http://creativecommons.org/licenses/ by-nc-sa/3.0)

"ASCB®" and "The American Society for Cell Biology ${ }^{\prime}$ " are registered trademarks of The American Society for Cell Biology. 
Students who have the opportunity to participate in collaborative discussion and engage in argumentation show an increase in knowledge and in their ability to use reasoning (Johnson et al., 1993; Johnson and Johnson, 1999). Engaging in argumentation also encourages students to think scientifically and exchange reasoning with peers (Kuhn, 1993; Koslowski, 1996; Zohar and Nemet, 2002; Asterhan and Schwartz, 2009) and to perform better on tasks that require the use of reasoning (Boa et al., 2009; Osborne, 2010). For example, Felton et al. (2015) showed that students who engaged in argumentation with the intention of reaching consensus were more likely to construct knowledge but also to increase the quality of their arguments. However, variation in the ways that students choose to interact can also have negative implications both within their current groups and on future individual performance (Weldon and Bellinger, 1997; Blumen et al., 2014; Barber et al., 2015; Marion and Thorley, 2016). Thus, understanding how students interact when solving problems in a group and exploring how reasoning is used in such settings may inform ways to implement peer discussion to generate high-quality learning experiences (Repice et al., 2016; Leupen et al., 2020).

Many studies have shown that student interactions are modulated by circumstance and context. For example, in the process-oriented guided-inquiry learning (POGIL) instructional approach, assigning students to take on specific roles during discussion can positively affect a group's productivity (Moog and Spencer, 2008). These assigned roles target students to a particular task, such as leading (manager or captain), presenting final conclusions (presenter or spokesperson), recording final conclusions (recorder), and reflecting on performance (reflector, document control, checker; Farrell et al., 1999). When implemented effectively, this approach can promote individual participation and cultivate functional groups (Simonson, 2019) and improve performance and retention. For example, undergraduates enrolled in a chemistry lab and biomechanics courses using the POGIL approach earned higher course grades than those in a non-POGIL course and were more likely overall to successfully complete the course (Farrell et al., 1999; Simonson and Shadle, 2013). An outstanding question is whether students need to be assigned to task-oriented roles to be successful. Eddy et al. (2015) showed that students may naturally gravitate to certain behaviors when placed into a group setting, but Farrell et al. (1999) noted that when students self-selected roles in group discussions, they usually chose behaviors with which they were most comfortable, possibly preventing them from challenging themselves.

The goal of this study was to characterize natural group interactions in relatively stable groups over time and to specifically explore the components of discussion that affected students' use of reasoning. We used the ICAP framework (Chi and Wylie, 2014) to provide theoretical backing for this work. The ICAP distinguishes between different types of active learning and describes the likely cognitive levels of understanding that can be achieved in each. Interactive is defined as multiple students collaboratively make inferences, while in constructive, students make inferences, enabling problem solving. These are distinguished from active, in which students receive information and connect it to prior knowledge, and passive, in which students only receive information. Chi and Wylie suggested that only when students engage in an interactive or constructive manner can they achieve higher-order learning. When interactive, students are both constructive and engaged with one another, working to create new ideas and meaning in a way that would not be possible individually. This is supported by other work (Osborne and Patterson, 2011) showing that when students act interactively, they can transition from using simple explanations to using reasoning to support their ideas. Smallgroup student discussions, which we used in this study, have the capacity to be interactive; however, they are by no means automatically so. Thus, there is a need to explore how students choose to engage in such settings, and how their engagement affects their use of reasoning.

In this study, we used a mixed-methods approach to explore natural student interactions in an introductory biology laboratory setting with three major goals: 1) characterize the behaviors of students engaged in unguided group discussion in which social and scientific interactions were expected but not explicit; 2) characterize student-chosen roles, their permanence, and their impact on other group dynamics; and 3) Characterize the use of reasoning in groups and whether it changes based on group interactions.

\section{METHODS}

\section{Characterization of the Course and Students}

All students were enrolled in a course-based undergraduate research experience (CURE) laboratory: Drug Discovery through Hands-on Screens, in which students in each section of the course worked as teams to screen for novel antibiotics using thousands of compounds from a small-molecule library and the bacterium Salmonella as a model system. The lab met in 2-hour sessions, twice a week for 15 weeks. There were six sections of 18-23 students per section, for a total of 121 students. In each of the sections, students interacted with one another, a faculty coordinator, and teaching assistants. Students self-selected into groups of three to five during the first week of class and generally maintained these groups over the course of the semester. For consenting students, we collected the following demographic data: gender, race/ethnicity, year, underrepresented minority (URM) status, first-generation status, and incoming standardized test scores (ACT or Scholastic Aptitude Test [SAT]; Table 1). Because we had a relatively low number of individual races and ethnicities reported, we grouped individuals not identifying as "white" under the acronym BIPOC (Black, Indigenous, and persons of color).

\section{Assignments and Discussions}

We developed a set of six assignments for this study (Figure 1); two individual, used as pre-post measures, and four used for group discussions during lab sessions over the course of the semester. All assignments presented experiments and data similar to the content of the course. We used an individual pre-post assignment to establish baseline and endpoint measures for each student, realizing that group discussions might not reflect how individuals process information by themselves. Students completed the pre assignment online before any group discussions and again online as part of one of their final assignments for the course (post). Each question included 1) an introduction with background information; 2) data in the form of a graph 
TABLE 1. Student demographics: Distribution of student sex, race/ethnicity, year in school, and incoming test scores

\begin{tabular}{lcccccrr}
\hline Sex & Percent & Race/ethnicity & Percent & \multicolumn{1}{c}{ Status } & Percent & Incoming performance & Average score \\
\hline Female & $72.2 \%$ & White & $71.1 \%$ & First year (freshman) & $60.8 \%$ & ACT Total & 27.86 \\
Male & $27.8 \%$ & BIPOC & $28.9 \%$ & URM status & $12.4 \%$ & ACT Math & 28.81 \\
& & & & First generation & $16.5 \%$ & SAT Total & SAT Math \\
& & & & & \multicolumn{2}{c}{ SAT } & \\
\hline
\end{tabular}

and raw numerical data; and 3) a prompt to provide claims, evidence, and reasoning (Figure 2).

For the in-class group discussions over the semester (Figure 3), each assignment was provided to students as a printed worksheet. Students were not specifically guided in any way before these discussions; thus, their responses were untrained with regard to producing claims, evidence, and reasoning during data analysis. Students audio-recorded themselves as they discussed the assignment, and the instructor collected the recordings as part of normal course work for participation credit. Of the 121 students enrolled in the course, 98 students in 30 groups agreed to have their assignment recordings used for research purposes (University of Colorado Institutional Review Board protocol 16-0511). We did not analyze recordings from groups with nonconsenting students. After the conclusion of the lab course, we transcribed the recordings verbatim. In most recordings, all students could be heard for the entirety of the discussion; however, due to seat location and/or voice projection, occasionally some turns of discussion were not audible and could not be included in the analysis. Only one discussion was mostly inaudible and thus could not be analyzed.

\section{Data Analysis}

We took a mixed-methods approach to data analysis, collecting quantitative measures on performance and participation and constructing detailed qualitative analyses of student interactions during discussion (Maxwell, 2013; Patton, 2009). All students were given pseudonyms.

Quantitative Features. We scored each student's individual answers (pre and post; $n=45$ ) as correct or incorrect and also noted the number and nature of reasoning statements made, as an indication of the student's ability to construct an argument (Table 2) For each of the group assignments, we determined the length of each discussion (minutes) and an individual's time spent talking to determine an individual's participation index (time the individual spent speaking/total time of discussion). We excluded off-topic turns-of-talk in the analysis.

\section{Qualitative Features}

Coding Student Behaviors and Roles during Group Discussion. Rather than attempting to use a previously developed coding scheme that might have forced us to apply a certain lens to

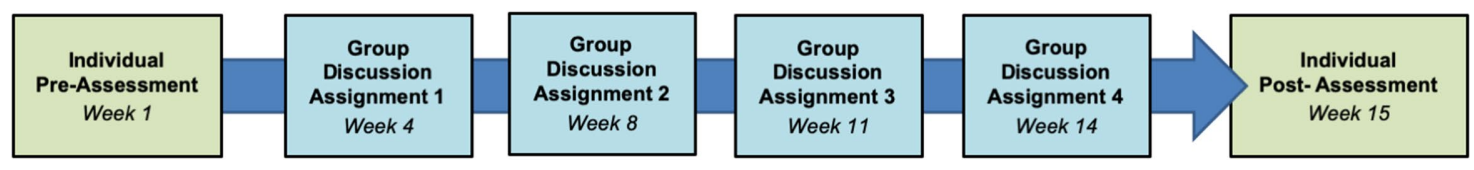

FIGURE 1. Order and timing of each assignment. All six assignments presented data from drug screens conducted on different bacterial strains.

In the Fall of 2017, students who participated in the Discovery Lab tested a compound library from the National Cancer Institute. They cultured Salmonella in the presence of a single compound (library compound or control) and determined the number of surviving Salmonella after treatment. A subset of the data is shown below.

\begin{tabular}{|c|c|c|c|c|c|c|}
\hline Researcher & $\begin{array}{c}\text { Compound } \\
\text { Identificatio } \\
\text { n Number }\end{array}$ & $\begin{array}{c}\text { Drug } \\
\text { Absorbance } \\
\# 1\end{array}$ & $\begin{array}{c}\text { Drug } \\
\text { Absorbance } \\
\# 2\end{array}$ & $\begin{array}{c}\text { Mean } \\
\text { Absorbance } \\
\text { of Drug }\end{array}$ & $\begin{array}{c}\text { Ampicillin } \\
\text { Absorbance }\end{array}$ & $\begin{array}{c}\text { DMSO } \\
\text { Absorbance }\end{array}$ \\
\hline MH & 1.1 & 0.1164 & 0.1148 & $\mathbf{0 . 1 1 5 6}$ & 0.0626 & 0.136 \\
\hline RS & 1.1 & 0.1598 & 0.1524 & $\mathbf{0 . 1 5 6 1}$ & 0.0584 & 0.1237 \\
\hline ER & 1.1 & 0.155 & 0.1391 & $\mathbf{0 . 1 4 7 1}$ & 0.0592 & 0.2022 \\
\hline PH & 1.1 & 0.2124 & 0.1903 & $\mathbf{0 . 2 0 1 3 5}$ & 0.0579 & 0.1555 \\
\hline MH & 1.2 & 0.1529 & 0.2051 & $\mathbf{0 . 1 7 9}$ & 0.056 & 0.1407 \\
\hline RS & 1.2 & 0.1856 & 0.1801 & $\mathbf{0 . 1 8 2 9}$ & 0.0544 & 0.1717 \\
\hline ER & 1.2 & 0.1771 & 0.1722 & $\mathbf{0 . 1 7 4 7}$ & 0.0549 & 0.1537 \\
\hline PH & 1.2 & 0.1454 & 0.1437 & $\mathbf{0 . 1 4 4 6}$ & 0.0559 & 0.1403 \\
\hline MH & 1.3 & 0.147 & 0.1367 & $\mathbf{0 . 1 4 1 9}$ & 0.0486 & 0.1444 \\
\hline RS & 1.3 & 0.1971 & 0.1768 & $\mathbf{0 . 1 8 7}$ & 0.0502 & 0.1726 \\
\hline ER & 1.3 & 0.1759 & 0.1379 & $\mathbf{0 . 1 5 6 9}$ & 0.0563 & 0.1882 \\
\hline PH & 1.3 & 0.1375 & 0.1377 & $\mathbf{0 . 1 3 7 6}$ & 0.0525 & 0.1398 \\
\hline
\end{tabular}

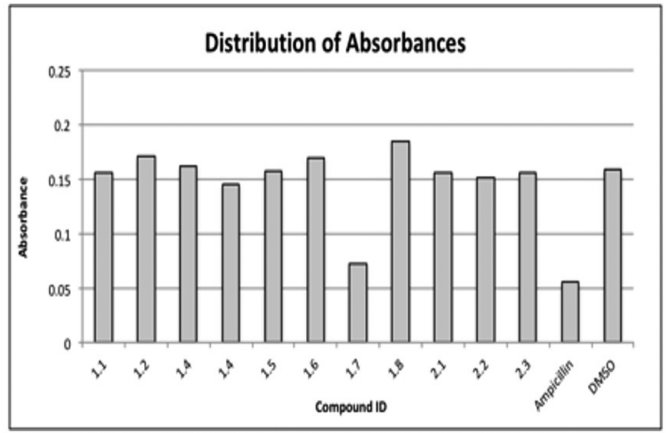

Distribution of Compound Absorbances. Salmonella were exposed to compounds individually. The absorbance of 600nm light was measure for each sample after 24 hours. Bars represent the average absorbance for each compound.

What conclusions can you draw from this data? Include your claim(s), evidence, and reasoning.

FIGURE 2. Pre and post assignment. Students completed the pre and post assignments individually at the beginning (week 1) and end (week 15) of the semester. 
Assignment 1: Mycobacterium tuberculosis are infectious bacteria that attacks the lungs and are becoming more and more resistant to current antibiotics. In the drug discovery lab, we are looking for possible compounds to act as new antibiotics for these bacterial infections. Students ran multiple compound screens (one compound per sample) in multiple repetitions on three compounds in a harmless Mycobacterium strain (same genius as tuberculosis). Students sent their results to scientists at the Center for Disease Control and Prevention (CDC) to be tested on this resistant strain of tuberculosis. Below is the data collected from both the students at the University of Research and the data collected by scientists at the CDC.

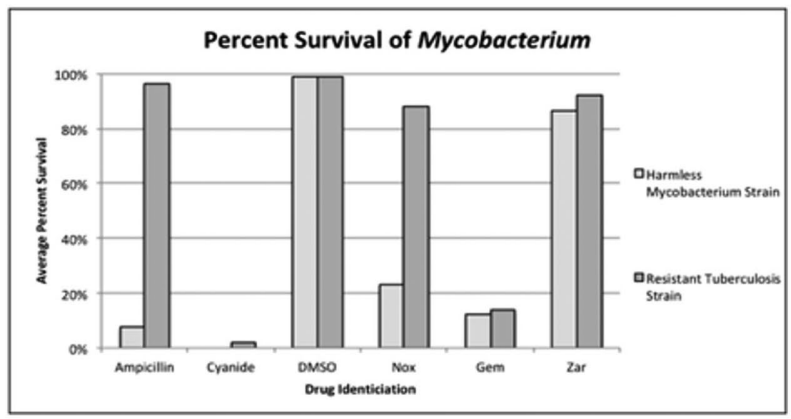

This graph shows the average percent survival of the bacteria after a 7-day treatment with drugs of interest (Nox, Gem, and Zar). Due to Mycobacterium tuberculosis being resistant to typical antibiotics, such as ampicillin, the CDC uses cyanide as a control (this is not an option for human treatment as cyanide is lethal to humans).

What conclusions can you draw from this data? Include your claim(s), evidence, and reasoning.

FIGURE 3. Example of a discussion assignment. A physical copy of the assignment was given to each student group, along with an audio recorder, at the beginning of the lab period. Students were asked to discuss the data and answer the questions while audio-recording their discussions.

our data, we started with an open-coding approach to capture whatever features were present in student discussions, using iterative content analysis (Saldana, 2015). During this emergent coding process, three coders read the same discussion transcripts and discussed the themes of students' language. We noted many features seen in our previous work on student discussions (Knight et al., 2013) as well as features of argumentation and problem solving described by others (Toulmin, 1958; Erduran et al., 2004, Osborne, 2010; Prevost and Lemons, 2016). Because no previously published set of codes directly captured the behaviors we were interested in, we developed categories reflective of previous work, but tailored to our own students' responses. Using three raters, we determined possible codes, discussing and revising, until we settled on 15 unique behavior codes. Using this final set, we coded the same subsets of discussion transcripts independently, adjudicating differences and continuing to iteratively refine the definitions of each code until we were satisfied. To establish reliability, all three raters then coded $10 \%$ of the remaining transcripts with an interrater agreement of $97 \%$ overall. We calculated interrater reliability for each code using Cohen's kappa (Gisev et al., 2013). Kappa coefficients ranged from 0.49 to 1 , with an overall average across all codes of 0.78 , indicating substantial agreement (Viera and Garrett, 2005). We then coded the remaining transcripts individually.

To establish student roles, as no prior published roles fit our data set, we used an iterative process similar to what we described earlier, noting styles of interaction and typical individual behaviors during each discussion. In the first cycle of role development, we identified 14 possible roles, which we reduced to 10 after a second cycle of coding and discussion. For each student, we also tallied their different behaviors in each discussion and used the predominance of a particular behavior to help guide the selection of a role for this student. With additional qualitative review of each transcript, students were then assigned to individual roles. A.P., J.K.K. and K.G. assigned roles to students in 17 discussions, reaching greater than $80 \%$ agree- ment. Kappa coefficients, calculated separately for each role, ranged from 0.58 to 0.9 , with an overall average Cohen's kappa of 0.78 , indicating substantial agreement. The remaining 74 discussions were coded individually.

Exchange of Quality of Reasoning. To describe engagement in reasoning, we used the Exchange of Quality Reasoning scale (Knight et al., 2013; Table 3). This scale was developed from Toulmin's components of argumentation (Toulmin, 1958) along with more recent work (e.g. Erduran et al., 2004) to generate a scale that privileged the participation of multiple students in developing an argument. As shown in Table 3, a level 0 discussion has no reasoning, while a level 3 discussion has more than one student exchanging reasoning tied to a claim with evidence (a "warrant"). We used the fine-grained behavioral coding scheme described earlier, tracking incidences of claims with reasoning, to give each discussion a score on the Exchange of Quality Reasoning scale. For this rating, all three coders rated all discussions, compared ratings, and reached consensus.

\section{RESULTS}

\section{Students Show Improvement in Correctness and Reasoning from Pre to Post}

Students were asked to complete an individual assignment at the beginning of the course and again at the end to be used as baseline and endpoint measures of their ability to analyze data and use reasoning; 45 of the 98 consenting students completed this assignment. Students were scored for correctness $(0 / 1)$ on the individual pre-post assignment. For the students who completed both assignments, there was a significant increase in individual performance, with $47.8 \%$ of students answering the pre assignment correctly, and $97.8 \%$ answering the post assignment correctly (exact McNemar's test, $p<0.001$; Cramer's V = 0.14; small effect size).

In addition to scoring correctness, we noted the number of reasoning statements, if made, in each student's individual 
TABLE 2. Correct answers and example reasoning statements for pre-post questions

\begin{tabular}{|c|c|c|}
\hline \multicolumn{3}{|c|}{ Scoring students pre-post assignment responses } \\
\hline & Correct answer $^{\mathrm{a}}$ & Observed student reasoning statements ${ }^{\mathrm{b}}$ \\
\hline $\begin{array}{l}\text { Pre-post } \\
\text { assignment }\end{array}$ & Compound ID 1.7 is the most effective at killing Salmonella. & $\begin{array}{l}\text { Because... } \\
\text { it has the lowest absorbance values } \\
\text { it is similar to the + control/ampicillin } \\
\text { it does not cause increased growth } \\
\text { it has been tested by multiple individuals } \\
\text { it provides consistent results } \\
\text { it is outside } 2 \text { standard deviations of the + control }\end{array}$ \\
\hline Assignment 1 & $\begin{array}{l}\text { Compound Gem is the most effective at killing Mycobacterium } \\
\text { tuberculosis. }\end{array}$ & $\begin{array}{l}\text { Because... } \\
\text { it has the lowest absorbance values } \\
\text { it is similar to the }+ \text { control/ampicillin } \\
\text { it has been tested by multiple individuals } \\
\text { it is outside } 2 \text { standard deviations of the + control }\end{array}$ \\
\hline Assignment 2 & Compound CA is the most effective at killing the Salmonella. & $\begin{array}{l}\text { Because.... } \\
\text { it has the lowest absorbance values } \\
\text { it is similar to the }+ \text { control/ ampicillin } \\
\text { it was tested in triplicate } \\
\text { it is outside } 2 \text { standard deviations of the + control }\end{array}$ \\
\hline Assignment 3 & $\begin{array}{l}\text { Compounds Faid and Bran are the most effective at killing the } \\
\text { Mycobacterium. }\end{array}$ & $\begin{array}{l}\text { Because... } \\
\text { they have the lowest absorbance values } \\
\text { they are similar to the + control/ampicillin } \\
\text { they have reliable standard deviations } \\
\text { they do not cause increased growth }\end{array}$ \\
\hline Assignment 4 & $\begin{array}{l}\text { Combinational treatments } \mathrm{W} 2+\text { Vet and } \mathrm{W} 6+\text { Vet are the most } \\
\text { effective at killing the Salmonella. }\end{array}$ & $\begin{array}{l}\text { Because... } \\
\text { they have the lowest absorbance values } \\
\text { they are similar to the }+ \text { control/ampicillin } \\
\text { they continue to cause death over time }\end{array}$ \\
\hline
\end{tabular}

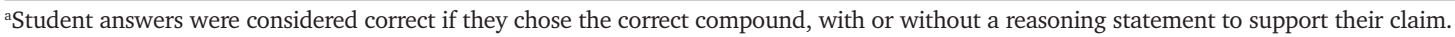

bReasoning statements were counted separately, as shown in the observed student reasoning statement column.

answer. For the students who completed both assignments, there was an overall significant increase in the number of reasoning statements from an average of 0.54 statements pre to an average of 0.85 post (Table 4A). Almost equal proportions of students never used reasoning or stayed the same in their use of a single reasoning statement. Twenty-six percent of students who showed an increase in reasoning did so by a single statement from pre to post (Table 4B). We further describe the types of evidence students used as reasons in Table 5. Of the 45 students who completed both the pre and post assignments, 23 provided the same piece of evidence to support their claims both pre and post, while about half either used different pieces of evidence or added more evidence to back their claims on the post. For example, Karah used the same evidence pre and post

\section{TABLE 3. Exchange of Quality Reasoning Scale levels}

\begin{tabular}{ll}
\hline Level $^{\text {a }}$ & \multicolumn{1}{c}{ Definition $^{\text {b }}$} \\
\hline 0 & No students made reasoning statements. \\
1 & Only one student used reasoning, which could include a \\
& warrant (no exchange). \\
2 & Two or more students exchanges reasoning, but neither or \\
& only one included a warrant. \\
& Two or more students exchanged reasoning, including \\
& warrants.
\end{tabular}

${ }^{a}$ Each transcript was assigned a level based on characteristics described.

${ }^{\mathrm{b}} \mathrm{A}$ warrant is a reasoning statement that directly connects evidence to a claim. A non-warrant reason is typically a "because" statement without a connection to evidence (from Knight et al., 2013). (comparing the absorbance of new compounds to the absorbance for the known antibiotic ampicillin) as her reason for choosing compounds as potential new antibiotics (a "hit"; Table $5 \mathrm{~A}$ ). On the other hand, Laura (Table 5B) used the positive control of ampicillin to explain her choice on the pre assessment and expanded her reasoning on the post assessment to include validating a compound as a hit, because it fell below 2 SD from DMSO, the chemical serving as the negative control. Similar to Laura, John further added in his post response that the results were reliable, because they were tested by multiple students.

\section{Individual Student Behaviors within Discussions}

Table 6A shows the set of detailed codes we developed to describe natural (unprompted) student behaviors during group

\section{TABLE 4. Reasoning in individual pre-post assignments}

A. The average number of reasoning statements used in the individual pre and post assignments for students who completed both $^{\mathrm{a}}$

\begin{tabular}{lc}
\hline Pre & $0.54(0.66)$ \\
Post & $0.85(0.07) *$ \\
\hline B. Change in number of reasoning statements pre to post \\
\hline Never used reasoning & $23.9 \%$ \\
One reason pre and post & $28.3 \%$ \\
Increased & $34.8 \%$ \\
Decreased & $13.0 \%$ \\
\hline
\end{tabular}

${ }^{a} n=46$; paired $t$ test, ${ }^{*} p<0.05$. Standard deviation shown in parentheses. 
discussions. Discussions frequently started with students either making a claim or beginning to analyze data. During this time, students noticed which compounds served as controls in the experiment or what kind of data were being presented. This was commonly followed by further data analysis and claims, sometimes supported with a reasoning statement. Students occasionally described future possible extensions to experiments, usually near the end of their discussions. Most students engaged in a repetitive pattern of analysis and claims with minimal reasoning; only a few groups exchanged claims with multiple statements of reasoning. Overall, students most frequently used analysis in their discussions (18.2\%), followed by noticing or recalling information $(9.7 \%)$ and making claims (9\%; Table 6B).

\section{Group Composition}

Students self-selected their groups, limited only by who else was in their lab section. We describe groups as homogeneous or heterogeneous in terms of gender and race/ethnicity (Table 7). The majority of students chose to form groups that were heterogeneous for race or gender (60\% for race; $63.3 \%$ for gender); $37 \%$ of these were heterogeneous for both. When students formed homogeneous groups, they were usually all white (11 of the 12 homogeneous race groups) and all female ( 9 of the 11 homogeneous gender groups).

\section{Exchange of Quality Reasoning Varies by Group}

Using the Exchange of Quality Reasoning scale (Table 3), we characterized the use of reasoning during each discussion (Figure 4A). Most discussions (72\%) did not use reasoning (level 0) or had reasoning by only one student (level 1). Some discussions contained exchanges of reasoning statements without directly tying their reasoning to a claim (level 2: 18\%), and only $5 \%$ of all discussions reached level 3, in which at least two students tied their claims directly to the supporting evidence with reasoning. Over the course of the four discussion assignments, group reasoning scores varied significantly (going either up or down), but on average, most groups stayed at level 1 . Of the 30 groups, 14 always engaged in low-quality discussions, two always engaged in high-quality discussions, and 14 fluctuated between higher- and lower-quality discussions (Figure 4B).

Figure 5 shows two different discussions that represent typical examples of low reasoning versus high reasoning. In the level 0 discussion (Figure 5A), students focused on extracting information about the data presented in the graph. They primarily listed what they observed rather than answering the question using claims and reasoning. They made a single claim: "W6 plus Vet really seems to improve the compounds," but provided no justification for this claim, failing to connect it to evidence presented. The students engaged in thinking about future directions and made comments on the quality of the data, but never circled back to a final conclusion. In contrast, a different group (Figure 5B) made multiple claims along with justifications for each of these claims. Altogether, they made a total of four different claims and a final conclusion statement with justification. Students in this example also engaged in analysis, but ultimately focused on drawing a conclusion with supporting evidence.

As shown in Table 8A, the frequency of specific behaviors was clearly different between groups who engaged in highquality reasoning versus low-quality reasoning. In high-quality discussions, students made claims and provided reasoning at significantly higher frequencies than students in low-quality discussions. On the other hand, students in low-quality discussions used analysis at a significantly higher frequency than those in high-quality discussions.

Differences in group composition (Table 7) can also affect the level of reasoning. For instance, we observed that groups heterogeneous for gender had significantly higher-quality discussions than homogeneous gender groups of either all male or all female $(p<0.01$, two-sample $t$ test; Cohen's $d=0.84$; large

TABLE 5. Examples of student pre-post assignment reasoning

\begin{tabular}{|c|c|c|c|}
\hline \multicolumn{4}{|c|}{ A. Examples of students who used similar reasoning on both the pre and post assignments $(n=23)$} \\
\hline \multicolumn{2}{|r|}{ Pre assessment reasoning statements } & \multicolumn{2}{|r|}{ Post assessment reasoning statements } \\
\hline Karah & $\begin{array}{l}\text { Compound } 1.7 \text { may be a potential antibiotic for } \\
\text { salmonella because it had a similar light } \\
\text { absorbance to ampicillin, an antibiotic. }\end{array}$ & Karah & $\begin{array}{l}\text { Compounds } 4.2 \text { and } 5.3 \text { might be hits because their absorbance } \\
\text { values are close to that of ampicillin, the positive control. }\end{array}$ \\
\hline \multicolumn{4}{|c|}{ B. Examples of students who used different reasoning on the post assignment $(n=22)$} \\
\hline & Pre assessment reasoning statements & & Post assessment reasoning statements \\
\hline John & $\begin{array}{l}\text { Ampicillin and compound } 1.7 \text { had low absorbance } \\
\text { rates ... The low absorbance indicates that the } \\
\text { compound was able to kill more of the bacteria, } \\
\text { leaving less bacteria behind to absorb the light. }\end{array}$ & John & $\begin{array}{l}\text { I think that it is safe to say that compounds } 4.2 \text { and } 5.3 \text { are statistical } \\
\text { hits, since they have a similar absorbance to ampicillin and would } \\
\text { most likely fall below two standard deviations of the negative } \\
\text { control (DMSO) if it were to be calculated. Since they were } \\
\text { separately tested by four students, there are enough replicates for } \\
\text { the results to be trustworthy. }\end{array}$ \\
\hline Laura & $\begin{array}{l}\text { Any other compound that may be a successful } \\
\text { antibiotic should have an absorbance rate after } \\
\text { culturing close to that of ampicillin. Looking at the } \\
\text { graph, the only compound with an absorbance } \\
\text { close to that of ampicillin is compound 1.7. }\end{array}$ & Laura & $\begin{array}{l}\text { Looking at compounds that may be hits, the way to determine if they } \\
\text { are indeed hits is to find the mean of the DMSO and subtract two } \\
\text { standard deviations from it. If the compound absorbance values } \\
\text { are below this, they are hits. Since we don't have this information, } \\
\text { looking at the graph we can just guess that compounds } 4.2 \text { and } \\
5.3 \text { will be below this value, especially since their absorbance } \\
\text { values are close to that of ampicillin. }\end{array}$ \\
\hline
\end{tabular}


TABLE 6. Individual line-by-line coding

\begin{tabular}{llr}
\hline A. Code definitions and frequencies ${ }^{\text {a }}$ & \multicolumn{1}{c}{ Definition } & $\begin{array}{c}\text { Average \% of turns } \\
\text { of talk per discussion }\end{array}$ \\
\hline Code & & $18.2(0.1)$ \\
Analyze & Using numbers or direct reference to the graph & $9.7(0.1)$ \\
Recall & Pointing out or recalling information needed to solve the problem & $9.3(0.1)$ \\
Repeat & Restating something that was already stated previously. Clarifying by restating. & $9.0(0.1)$ \\
Claim & Stating answer to applicable problem & $5.0(0.1)$ \\
Extend & Suggesting further analysis of experiments & $4.8(0.1)$ \\
Reason & Defending a claim/statement/idea with a reason connected to evidence & $4.0(0.1)$ \\
Question & Asking a question in order to better understand. General statements of confusion. & $3.7(0.1)$ \\
Affirm & Making statements of agreement & $2.1(<0.1)$ \\
Focus attention & Reading questions or asking to move on & $2.1(<0.1)$ \\
Teach & Explaining something to another student & $1.6(<0.1)$ \\
Drive discussion & Keeping discussion on track. Asking questions of others to facilitate discussion & $0.7(<0.1)$ \\
Agree & Reaching a final consensus after disagreement & $0.7(<0.1)$ \\
Disagree & Stating disagreement with a claim/statement/idea & $0.7(<0.1)$ \\
Divert & Pulling attention away from the main content of the question & $26.3(0.2)$ \\
Other & Off-topic & \\
\hline
\end{tabular}

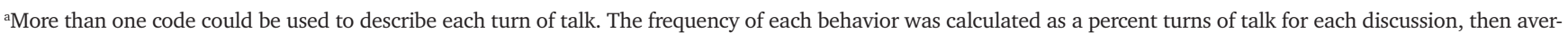
aged across the 91 discussions. On average, discussions contained $21.3( \pm 10)$ turns of talk. Standard Deviation is shown in parentheses.

\begin{tabular}{|c|c|c|}
\hline \multicolumn{3}{|c|}{ B. Transcript from one group discussion, with associated codes for each turn of talk } \\
\hline Student & Dialogue & Code \\
\hline Kelly & The negative control is DMSO. & Recall \\
\hline Samuel & $\begin{array}{l}\text { So it initially looks like the compounds, Faid and Bran maybe were like the best ones at killing the } \\
\text { mycobacterium um, because as shown in the graph, they had the least amount of absorbance. } \\
\text { They were the most similar to ampicillin after the incubation period. }\end{array}$ & $\begin{array}{l}\text { Claim } \\
\text { Reason }\end{array}$ \\
\hline Kelly & $\begin{array}{l}\text { Um and because each compound was tested in triplicate by two students, like that's pretty good. But } \\
\text { for the ones that showed that they were hits, that they were low, they should probably be tested a } \\
\text { few more times just to be sure that they are killing the bacterium. }\end{array}$ & Extend \\
\hline
\end{tabular}

effect size). On the other hand, there was no difference in quality of reasoning between groups that were homogeneous versus heterogeneous for race/ethnicity (Figure 6).

Finally, despite variations in their exchange of reasoning, groups overall performed similarly on all assignments, with a range of $79-87 \%$ of groups providing a correct answer for assignments 1-4. A chi-square test of independence showed that there were no significant differences in performance across the four group assignments.

\section{Students' Behaviors Classified Them into Roles}

Using the codes ascribed to each individual, we established roles that captured the characteristics of an individual's behaviors during discussion. Of the 10 roles we identified, four were most common: analyst, reasoner, generalist, and minimalist (Table 9). A minimalist was defined as someone who spoke only once or twice in a discussion and did not contribute meaningfully to completing the assignment. The other common roles are presented with examples.

TABLE 7. Group composition with regard to gender and race/ethnicitya

\begin{tabular}{lrccc}
\hline Heterogeneous for gender & 19 & & & \\
Homogeneous for gender & 11 & All male & All female & \\
Heterogeneous for race/ethnicity & 18 & & All BIPOC \\
Homogeneous for race/ethnicity & 12 & All white & & \\
Heterogenous for both & 11 & & All Female \\
Homogenous for both & 3 & All White & & 3 \\
Total groups & 30 & & & \\
\hline
\end{tabular}

${ }^{\mathrm{a}}$ Of the 30 groups, most were heterogeneous for either gender or race/ethnicity. Some were heterogeneous for both. 

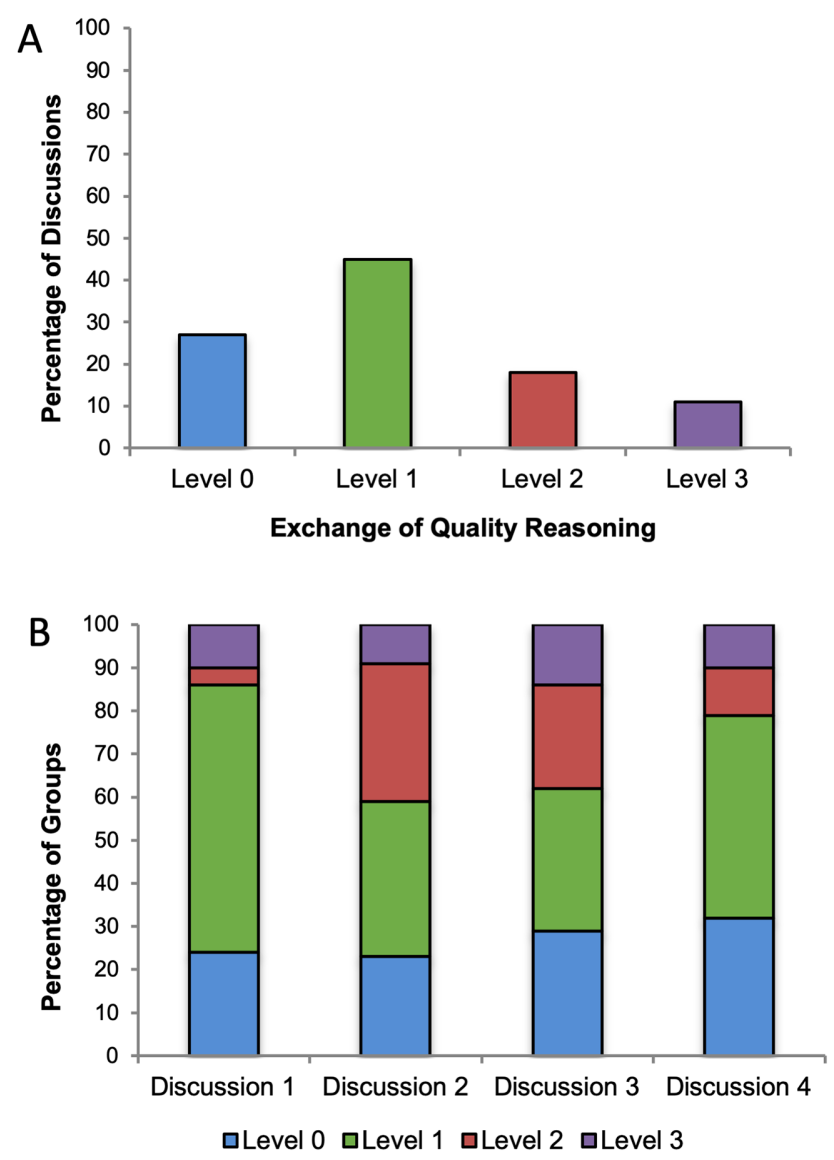

FIGURE 4. Distribution of Exchange of Quality Reasoning scale scores. (A) The majority of group discussions had low-quality reasoning (level 0 or 1 ) across all assignments, with only $5 \%$ reaching level 3. (B) Using a chi-squared test for association, groups vary significantly across the four discussions; $\chi^{2}(9, N=91)=41.849$, $p=3.502 \mathrm{e}-06$; Cramer's V $=0.18$; small effect size.

The role of analyst was well illustrated by Andrew. Andrew primarily analyzed data, including describing the graphical data presented and identifying the percent survival of each strain. Andrew stated:

A lot of the resistant tuberculosis survived but not a lot of harmless Mycobacterium survived. But with the cyanide practically nothing survived ... DMSO, Nox, and Zar had at least $80 \%$ survival in the resistant strain ... Gem only has $20 \%$ survival in the resistant strain ... Gem is definitely more successful than Nox and Zar.

During a different discussion, Rakel took on the role of reasoner, responding to the question prompt with:

You can't use AC [...] as a for sure hit because you only have one trial. Then the next one we looked at that could possibly be a hit was CA [...], that one looks like the most reliable because it has very consistent ampicillin values and it has consistent DMSO values and the drug. It's kind of off a little bit, but for three trials it's pretty good. For BB, yah, for BC too, um, [...] similar ampicillin and similar DMSO, and that's kind of the same thing with CB. These ones are not hits, but, um, are more reliable data."

Rakel used a series of "because" statements when referring to the reliability of the data for compound AC and again when she explained why CA could be a hit by comparing it to the values of the controls. The use of these statements qualified Rakel as a reasoner: someone who made multiple claims with justification statements.

The role of generalist was defined as one who engaged in multiple different behaviors, with no clear theme. For example, Gina asked a question: "How can cyanide be a control?"; then made a claim: "The least effective one would be this one [referring to the drug Mas]"; later analyzed data: "the resistant strain looks like it especially resistant to the ampicillin"; and finally, drove the discussion: "Do you want to say more?" Her varied contributions are typical of those classified as generalists.

Several additional less-common roles also provide insight into student behaviors. A knowledge facilitator was someone who engaged in teaching other students by helping them understand the data. This role is demonstrated by Noel's dialogue in response to a question about a control:

\section{So, the DMSO, essentially, the point of it, by testing DMSO on its own you know that it is not actively harming any bacteria that it is in because then you wouldn't know how efficient the actual compound is. So, in a sense cyanide, ampicillin, and DMSO are all controls, 'cause ampicillin you want to know actually works on a non-resistant strain and that it no longer works on a resistant strain.}

The role of driver was the least common (only five instances total). Students who took on this role engaged in leadership, in which they focused on asking questions of others to direct the conversation forward. For example, Jess served as a driver when she attempted to refocus the attention of her group members to the problem by requesting information through a series of statements: "[Does] anyone want to make a claim?" and "Does anyone want to mention Mas or Bran?"

\section{Some Students Show Preference for a Specific Role, but Many Change Roles}

We grouped students into three categories by their likelihood to maintain the same role over the four discussions. Although we use the term "preference" for these categories, there is no evidence that students are conscious of their role choices. In the "no preference" category, students took on a different role for each discussion; in "some preference," students took on the same role for more than $50 \%$ of the discussions; and in "strict preference," students always took on the same role for all discussions in which they participated (Table 10A). Among the students who showed a role preference, the most common was analyst (Table 10B).

Although it was common for students to vary their roles, it is noteworthy that, in some cases, students appeared to change their roles in response to the absence of a formerly dominant individual. We defined dominators as students whose participation index was greater than $50 \%$, where the participation index is student's total minutes spent talking/ total time of discussion. There were dominators in 19 of 91 


\begin{tabular}{|c|c|c|c|c|c|}
\hline \multicolumn{3}{|c|}{ A. Low Quality of Reasoning Discussion (Level 0 ) } & \multicolumn{3}{|c|}{ B. High Quality of Reasoning Discussion (Level 3) } \\
\hline Student & Dialogue & Code(s) & Student & Dialogue & Code(s) \\
\hline Katie & Um, so the DMSO is their negative control & Recall. & \multirow{3}{*}{ Sarah } & \multirow{3}{*}{$\begin{array}{l}\text { So the question asks, what conclusions can you } \\
\text { draw from this data. Include your claims. Evidence, } \\
\text { and reasoning. One piece of evidence you might } \\
\text { want to consider is the variability in the data }\end{array}$} & \multirow{3}{*}{$\begin{array}{l}\text { Focusing } \\
\text { attention }\end{array}$} \\
\hline Ellen & $\begin{array}{l}\text { The positive control is ampicillin. So that is what we are going to compare } \\
\text { the tested things to. }\end{array}$ & Recall. & & & \\
\hline Katie & Um, whatever W2 plus Vet is, literally killed everything & Analysis. & & & \\
\hline Steven & The ampicillin, the absorbance goes up in the end for a lot of them & Analysis. & \multirow{3}{*}{ Melissa } & \multirow{3}{*}{$\begin{array}{l}\text { It looks like none of the drugs are making it grow } \\
\text { because none of the drugs are above } 2.25 \text {. There } \\
\text { are a couple that obviously kill it because the } \\
\text { absorbance is low. }\end{array}$} & \multirow{3}{*}{$\begin{array}{l}\text { Claim. } \\
\text { Justify. } \\
\text { Analysis. }\end{array}$} \\
\hline Katie & Is that like a the ampicillin like wears off, or is it the & Question. & & & \\
\hline Steven & Yah, interesting where as the $\mathrm{W} 2$ plus Vet, there is no further increase & Analysis. & & & \\
\hline Katie & So the W2 is like killing it up until day 10 but then it grows back & Analysis. & \multirow{2}{*}{ Sarah } & \multirow{2}{*}{$\begin{array}{l}\text { I think that it looks like whatever Regg is is making } \\
\text { it grow because that is like higher than DMSO. }\end{array}$} & \multirow{2}{*}{$\begin{array}{l}\text { Claim. } \\
\text { Justify. }\end{array}$} \\
\hline Ellen & But the weird thing is that ampicillin does as well & Repeat. & & & \\
\hline Steven & $\begin{array}{l}\text { So I am guessing that its just the fact, maybe what the vet does, wait how } \\
\text { long does this say this lasted? The absorbance one. }\end{array}$ & Question. & Melissa & $\begin{array}{l}\text { Oh, is it like uh, is the standard deviation like, does } \\
\text { it show }\end{array}$ & Recall. \\
\hline Ellen & Um, it doesn't say, I think that this is after 24 hours & & \multirow[b]{2}{*}{ Sarah } & \multirow{2}{*}{$\begin{array}{l}\text { Oh yah the standard deviation for Regg is really } \\
\text { high so that is not super reliable. Also for Pratt so } \\
\text { that could be like a limitation in their data. }\end{array}$} & \multirow[b]{2}{*}{ Analysis. } \\
\hline Steven & $\begin{array}{l}\text { Oh ok, so I just want to see, where is W6 plus Vet on that graph? Oh W6 } \\
\text { kills everything by day } 8 \text {. So W6 plus this Vet thing really seems to }\end{array}$ & Analysis. & & & \\
\hline Ellen & $\begin{array}{l}\text { Ok so the biggest thing I think that they should do if they are going to } \\
\text { retest is ampicillin plus vet, and look at that after } 14 \text { days }\end{array}$ & Extension. & Melissa & $\begin{array}{l}\text { And then Faid seems to be like the one that seems } \\
\text { to be killing the the bacteria the most since it had a } \\
\text { lower absorbance }\end{array}$ & $\begin{array}{l}\text { Claim. } \\
\text { Justify. }\end{array}$ \\
\hline \multirow[t]{2}{*}{ Steven } & \multirow{2}{*}{$\begin{array}{l}I^{\prime} m \text { also curious about that too. Granted I'm not a scientist but I'm } \\
\text { guessing that what Vet does is that in some way it prolongs the life of the } \\
\text { um, like whatever its called, it prolongs how long antibiotics take. }\end{array}$} & \multirow{2}{*}{ Analysis. } & Becky & Was this tested two times? & Question \\
\hline & & & \multirow{2}{*}{ Sarah } & \multirow{2}{*}{$\begin{array}{l}\text { Two time in triplicate. Yah triplicates are pretty } \\
\text { reliable but I guess it could be done more. }\end{array}$} & Teaching. \\
\hline \multirow{3}{*}{ Katie } & \multirow{3}{*}{$\begin{array}{l}\text { Yah I mean for most of these except for YO, vet helps with the } \\
\text { combination drug therapy, except for in YO cuz I do not know what that is } \\
\text { so they should probably test that again. Its also like the single and } \\
\text { combination drug treatments uh, its listed, it was measured after } 6 \text { days } \\
\text { and this one starts after } 6 \text { days. I am curious what it would look like after } \\
24 \text { hours. }\end{array}$} & \multirow{3}{*}{ Extension. } & & & Extension. \\
\hline & & & Sarah & $\begin{array}{l}\text { But um, the fact that Faid had such a low standard } \\
\text { deviation probably suggests that it could be a hit }\end{array}$ & $\begin{array}{l}\text { Claim. } \\
\text { Justify. }\end{array}$ \\
\hline & & & Melissa & And it is about the same as ampicillin or a little less & Analysis \\
\hline Steven & Um it would probably look somewhat similar. & & Becky & Even less than ampicillin if anything & Repeat. \\
\hline Katie & But then its like what is the lifespan of these antibiotics? & Question. & \multirow[b]{2}{*}{ Melissa } & \multirow{2}{*}{$\begin{array}{l}\text { So is Bran and Mass, they are pretty close to } \\
\text { ampicillin. I think that Regg, you can not say that it } \\
\text { made it grow because the standard deviation is } 1 .\end{array}$} & \multirow{2}{*}{$\begin{array}{l}\text { Analysis. } \\
\text { Justify. }\end{array}$} \\
\hline \multirow[t]{2}{*}{ Steven } & \multirow{2}{*}{$\begin{array}{l}\text { I think that is what it is trying to illustrate, is that even like ampicillin, } \\
\text { which is seen as a good antibiotic, after } 8 \text { days it is basically gone so } \\
\text { whatever this Vet thing is, its supposed to, what do you call it. Alright } \\
\text { anything else you guys want to add? }\end{array}$} & \multirow[t]{2}{*}{ Recall. } & & & \\
\hline & & & Sarah & So Fiad was the most promising one. & Repeat. \\
\hline
\end{tabular}

FIGURE 5. Example transcripts of low and high Exchange of Quality Reasoning discussions. A. A low-level discussion in which students primarily list observations about the data, discuss future experiments, and do not make a clear claim. B. A high-level discussion in which students make a variety of claims with justifications.

discussions. In most cases, this behavior was exhibited by different individuals in different groups, and by both males and females equally. However, in four groups, a single individual (a male in three cases, a female in one case) consistently exhibited dominant behavior. In each of the instances when this dominant individual was present, they contributed most or all of the arguments used by the group to draw conclusions. Thus, all of those discussions were coded as a 1 on the Exchange of Quality of Reasoning scale. However, when the dominant individual was not present in a particular discussion, as occurred on two occasions for two different groups, the remaining students increased their use of reasoning, with one group reaching a level 2 and the other, a level 3 on the Exchange of Quality of Reasoning scale. This change is represented by Nathan's group, shown in Figure 7. Nathan generally dominated the discussion, as seen by his introductory statement:

Cyanide is the control that they used in this experiment and definitely has the lowest survival in both the harmless mycobacterium and the resistant tuberculosis strain, but that one you are not able to use. It is not an option for human treatment. Gem looks really promising, it is less than $20 \%$ for both the harmless mycobacterium and the resistant tuberculosis strain over 7 days.

Here, Nathan acted as a reasoner and analyst, noticing components of the question, analyzing data, making a claim, and justifying his claim by providing data to support it. Perhaps in response to the strength of his statements, the other three group members took on supporting roles of generalist (two group members) and driver (one group member) in both discussions 1 and 3. However, when Nathan was absent in discussion 2, the

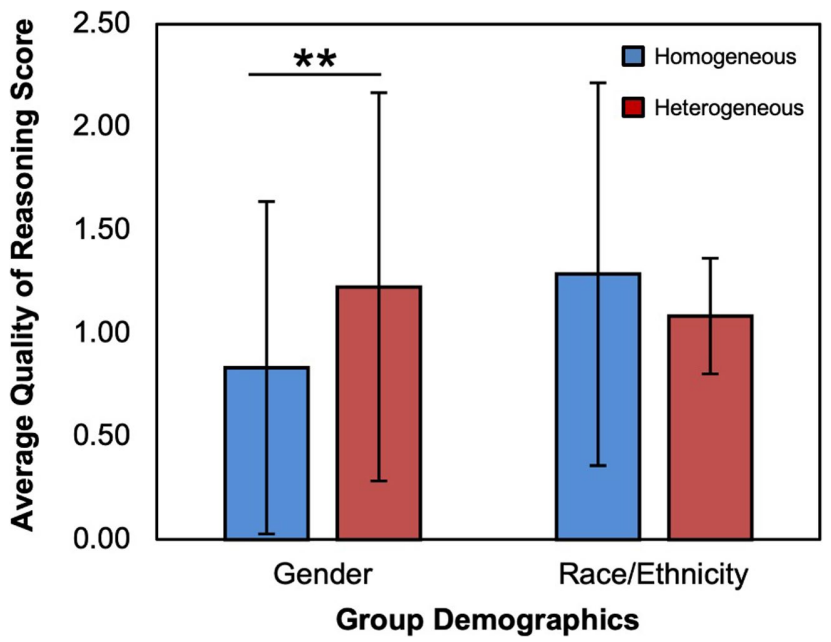

FIGURE 6. Group Heterogeneity and Quality of Reasoning. Average Exchange of Quality Reasoning scores for groups that were homo- or heterogeneous for either gender or race/ethnicity; $\mathrm{n}=\mathbf{3 0}$ groups. Students in heterogeneous groups in terms of gender showed significantly higher scores ${ }^{* *} p<0.01$, two-sample t-test; Cohen's d = 0.84; large effect size. 
TABLE 8. Prevalence of behaviors and roles in low vs. high-quality of reasoning discussions ${ }^{\mathrm{a}}$

\begin{tabular}{|c|c|c|c|}
\hline \multicolumn{4}{|c|}{ A. Prevalence of specific behaviors ${ }^{b}$} \\
\hline Behavior & & Low & High \\
\hline Claim & & $8.1 \%$ & $11.9 \% *$ \\
\hline Reason & & $2.9 \%$ & $9.7 \% * *$ \\
\hline \multicolumn{4}{|c|}{$\underline{B}$. Prevalence of common roles ${ }^{c}$} \\
\hline \multicolumn{2}{|c|}{ Roles in low-quality discussions } & \multicolumn{2}{|c|}{ Roles in high-quality discussions } \\
\hline Generalist & $19.3 \%$ & Generalist & $22.6 \%$ \\
\hline Minimalist & $18.3 \%$ & Minimalist & $17.2 \%$ \\
\hline Reasoner and Analyst & $7.8 \%$ & Reasoner and Analyst & $16.1 \%$ \\
\hline Reasoner & $6.4 \%$ & Analyst & $11.8 \%$ \\
\hline
\end{tabular}

aDiscussions were binned into low-quality (levels 0 and 1) and high-quality (levels 2and 3) reasoning discussions.

${ }^{b}$ The frequency of each behavior was calculated as a proportion of all codes (total of 2408 codes).

'The frequency for each type of role preference was calculated for each of the 121 students across all discussions. Roles are listed from high to low prevalence. $* * p<0.01$; $* * * p<0.001$; two-sample $t$ test.

student interactions were different. The other students now took on the roles Nathan had previously performed, and all contributed equally to the discussion. For example, Sarah now took on the role of the reasoner, in which she made a claim and then justified her choice by comparing the compound she chose to the control:

What we see is AC is the most effective. It is even more effective than ampicillin ... The least effective was AA. The ampicillin and DMSO looked pretty even for that so I would say that is actually not too effective.

Chris also took on the role of reasoner by making similar statements:

Yah, the only drugs I see that were effective, like way below the DMSO, were AC, BA, and CA [...]. For CA, the data is pretty consistent so I would say that is probably the best drug of the bunch.
These examples illustrate that a dominator can negatively affect a group's exchange of reasoning, but that students can also shift their roles in the absence of a dominator.

\section{DISCUSSION \\ Limitations}

We collected data in the form of written individual responses and recorded group discussions across four different time points in the context of a CURE laboratory course. These data allowed us to draw conclusions about how students in this specific environment interacted with one another when completing data-analysis assignments. However, students in different laboratory environments, or even the same laboratory environment but with different group assignments, may choose to behave differently.

Our study was also limited by sample size and relative homogeneity. Although we were able to gather rich qualitative data from recorded group interactions, our sample did not allow us to determine the statistical significance of all of our

TABLE 9. Student roles: Definition and prevalence of each role

\begin{tabular}{|c|c|c|c|}
\hline$\underline{\text { Role }}$ & Definition & $\begin{array}{c}\text { Number of times } \\
\text { individuals take on a } \\
\text { role }(\%)\end{array}$ & $\begin{array}{c}\text { Number of groups } \\
\text { that included a } \\
\text { role }(\%)\end{array}$ \\
\hline Analyst & $\begin{array}{l}\text { Interprets data by describing tables or graphs, and thinks of } \\
\text { alternative interpretations or experiments }\end{array}$ & $129(36)$ & $75(82)$ \\
\hline Reasoner & $\begin{array}{l}\text { Explains the reasons behind a claim; justifies the final answer; } \\
\text { may also make claims and notice }\end{array}$ & $72(20)$ & $53(58)$ \\
\hline Generalist & $\begin{array}{l}\text { Engages in a variety of behaviors in a relatively equal mix; does } \\
\text { not provide any major contributions }\end{array}$ & $60(17)$ & $44(48)$ \\
\hline Solver & Only makes claims without any reasoning & 14(4) & $13(14)$ \\
\hline Observer & Only notices or recalls information & $7(2)$ & $6(7)$ \\
\hline Discussion driver & $\begin{array}{l}\text { Promotes conversation by focusing attention of group members } \\
\text { and driving the discussion forward }\end{array}$ & $5(1)$ & $6(7)$ \\
\hline Affirmer & Rewords previous claims or makes statements of agreement & $5(1)$ & $6(7)$ \\
\hline Knowledge facilitator & Drives development of understanding by teaching others & $5(1)$ & $2(2)$ \\
\hline \multirow[t]{2}{*}{ Questioner } & Asks clarification questions or requests explanations & $2(>1)$ & $1(1)$ \\
\hline & & 357 total individual roles & 91 total group discussion \\
\hline
\end{tabular}


TABLE 10. Individual consistency in role selection

\begin{tabular}{|c|c|c|c|c|c|}
\hline \multirow[t]{4}{*}{ A. } & \multicolumn{5}{|c|}{$\begin{array}{l}\text { Percent of students } \\
\quad(n=109)\end{array}$} \\
\hline & \multicolumn{2}{|c|}{ No preference } & \multicolumn{2}{|l|}{$49.2 \%$} & \\
\hline & \multicolumn{2}{|c|}{ Some preference } & \multicolumn{2}{|l|}{$27.4 \%$} & \\
\hline & \multicolumn{2}{|c|}{ Strict preference } & \multicolumn{2}{|l|}{$23.4 \%$} & \\
\hline \multirow[t]{3}{*}{ B. } & \multicolumn{5}{|c|}{$\begin{array}{l}\text { Roles students chose to assume when they had strict role } \\
\text { preference }(n=29)\end{array}$} \\
\hline & Reasoner & Analyst & Minimalist & Other & \\
\hline & 6 & 14 & 6 & 3 & $\begin{array}{l}\text { i.e., driver, affirmer, } \\
\text { observer }\end{array}$ \\
\hline
\end{tabular}

aThe frequency for each type of role preference was calculated for all students across all discussions.

observations or explore all possible questions pertaining to gender and race/ethnicity.

Finally, the individual pre-post assignment and the group discussion assignments were graded for participation rather than for correctness. The purpose of this was to capture ideas and more organic discussion with less pressure of reaching a correct conclusion; however, students may have chosen not to participate (as in the case of the post assignment) or participated with less organization and effort during the in-class assignments if they were not motivated to perform to the best of their ability. Thus, we may not have captured students' full capacity for collaboration and reasoning.

\section{Students Need Explicit Instruction in Reasoning}

Science process skills like data analysis and reasoning are an important part of scientific endeavors such as solving problems, designing experiments, and communicating results (DebBurman, 2002; Dirks and Cunningham, 2006; Lubben, 2009; Coil et al., 2010). These skills are not intuitive for most students, and the act of providing reasoning during problem solving is difficult for students at all levels (Kitchen et al., 2003; Erduan et al., 2004; McNeill and Krajcik 2008). Past efforts to improve students' science process skills have suggested that practice and hands-on laboratory experience foster an environment that allows for the development of reasoning skills (Kanari and Millar, 2004; Kitchen and McDougall, 1999).

In this study, we found that, despite being in a laboratory environment, students focused primarily on analyzing data without using reasoning. We measured their exchanges of reasoning as one indication of their ability to be collaborative, finding that only $53.2 \%$ of student claims were backed by reasoning, and only $58 \%$ of groups contained a reasoner (Table 9). This shortage may indicate that the data presented to students were not complex enough to draw out reasoning (Paulus, 2005) and/or that students were not comfortable providing evidence to support the claim(s) they were making (Erduan et al. 2004; McNeill and Krajcik, 2008). Students may easily recognize evidence but may not understand how to use evidence in constructing reasoning (Sampson et al., 2011; Zembal-Saul et al., 2012). If they do not understand what constitutes a reason in a science setting (McNeill and Krajcik, 2007; Sandoval and Reiser, 2004), they are likely to provide descriptions of data rather than explanations (Driver et al., 2000; Sandoval and Millwood, 2005; McNeill et al., 2006). From the observations we collected, it seems likely that students are unsure about what qualifies as reasoning. In several instances, students state that they are done with the assignment, because they have already supplied reasoning, when in fact they have only made a series of claims and observations. Thus, there is a disconnect between students' perception of providing reasoning and the actual use of reasoning as defined by instructors.

Previous studies (Johnson et al., 1991, 1993; Johnson and Lawson, 1998; Krejins et al., 2003; Tanner et al., 2003; Osborne, 2010; Premo et al., 2018) have also shown that putting students into groups is not necessarily sufficient to generate collaboration. Our findings support this observation: most of the students in our study participated in group work without engaging in the interactive or constructive ways promoted by Chi and Wylie (2014) that would transition them from simple explanations to generative thinking that includes reasoning. Thus, it seems clear that, even in a group laboratory setting,
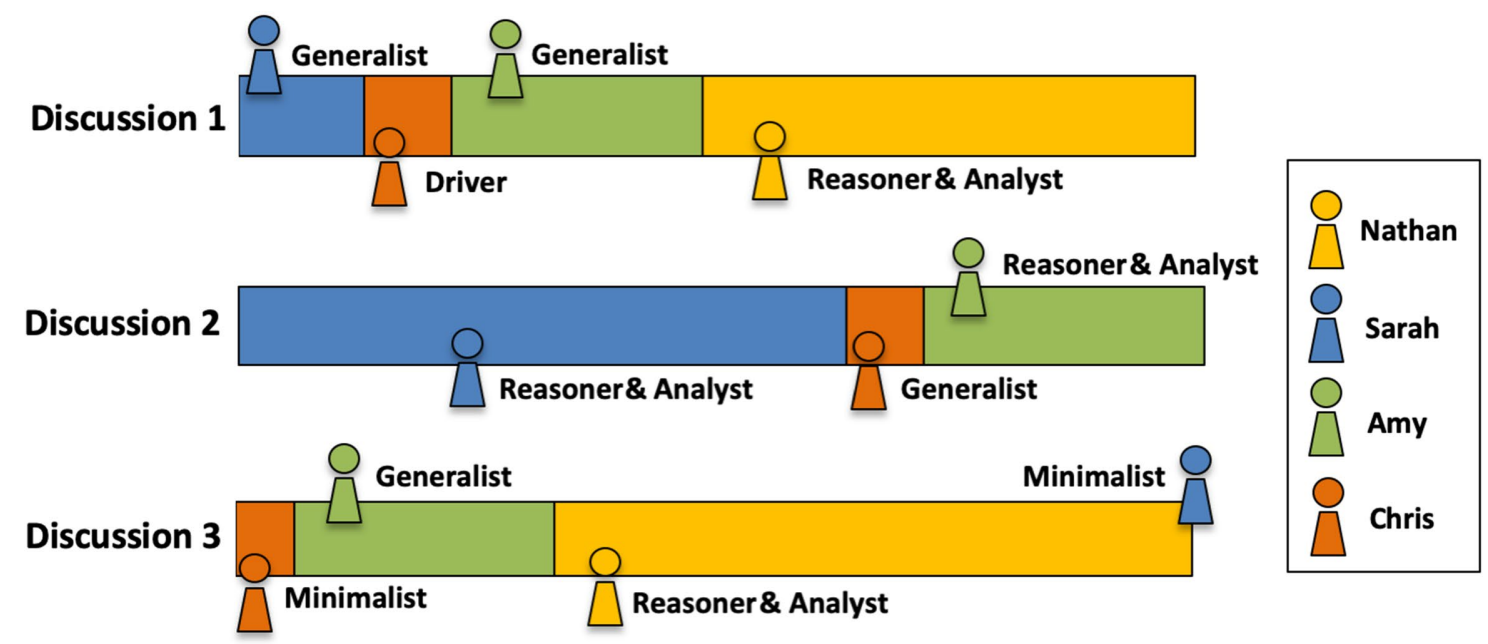

FIGURE 7. Roles and contributions can change across discussions. The roles taken by different members of a single group over three discussions (students were absent for the fourth discussion). The participation index for each student is shown as a bar and is labeled with their respective role(s). 


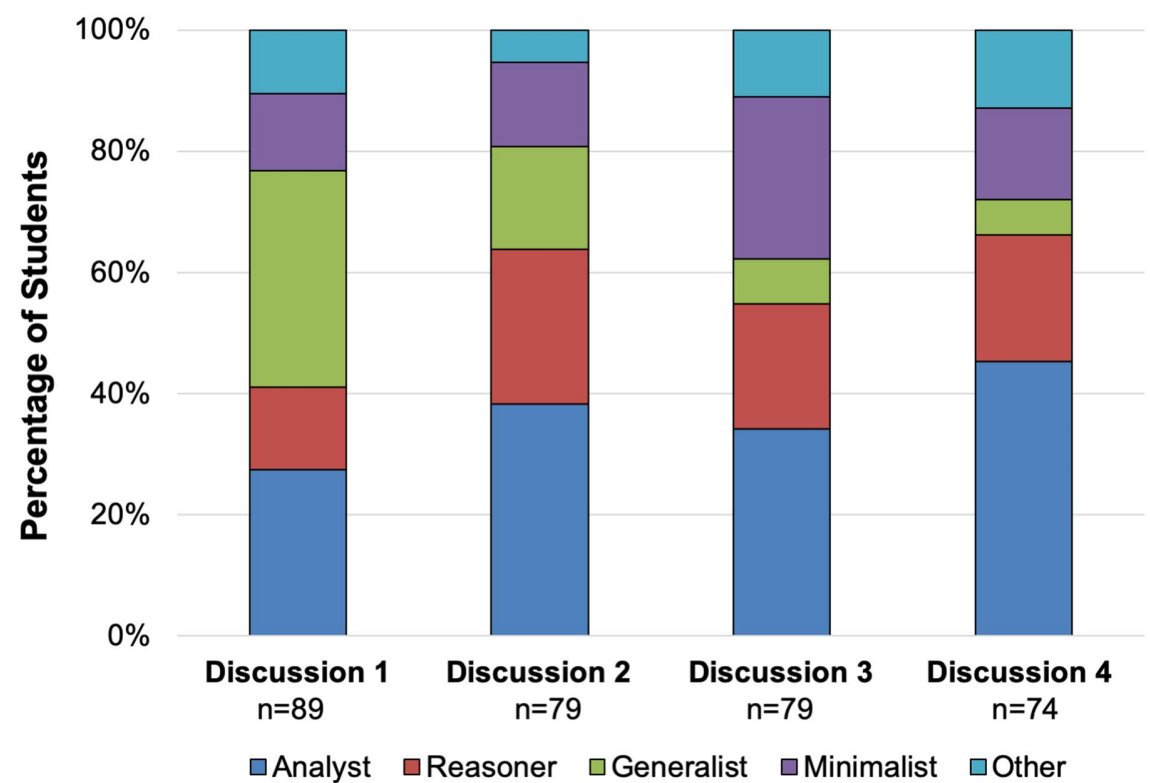

FIGURE 8. Distribution of observed student roles for each of the four group discussions. The percent of students who took on each role is shown for each discussion. According to a chi-squared test for association, the groups are not significantly different from one another $\chi^{2}=(12, N=91)=17.51, p=0.1267$. Across the four discussions, the distribution of student roles differed slightly, although not significantly/ Although the role of Analyst was always the most prevalent, fewer students were classified as Generalists and more as Reasoner after Discussion 1.

where students are theoretically free to explore their ideas and ask one another questions, they still need explicit instruction in how to use reasoning, from what reasoning is to how to implement it during data analysis and discussion, and frequent reminders to employ such reasoning.

\section{Heterogeneity is Beneficial for Group Discussions}

Previous studies have shown that an individual's gender may influence his or her participation (e.g. Tolmie and Howe, 1993). In one study of college students, males often reported taking on leadership roles during group discussions, while female students preferred to be collaborators (Eddy et al., 2014). Similarly, in a study of South African middle school students, males took on a more authoritative approach to the problems, and females focused more on democratic approaches and reaching consensus (Lubben, 2009). In the current study, mixed-gender groups had relatively equal participation (measured by turns of talk), and, overall, an equal number of males and females took on dominating roles in discussions. Nonetheless, when a group consistently had a dominator, it was a male in three of the four groups. These results support the previous findings that males and females may interact differently in their groups, potentially depending on the makeup and dynamic of the group. We also found that mixed-gender groups reached higher-quality of reasoning levels than homogeneous gender groups (Figure 6A), although some homogenous (all female) groups were also highly collaborative. Due to the strength of the effect size for the higher reasoning levels of heterogeneous gender groups, instructors may wish to monitor the makeup of groups and encourage students to form, or assign students to, mixed-gen- der groups. By doing so, instructors can promote equity and an environment more conducive to sharing reasoning.

As far as racial and ethnic makeup of groups, prior studies have shown a positive impact of heterogeneity in these cases as well, demonstrating the value of having various opinions and perspectives to generate novel solutions (Howard et al., 2002; McLeod and Lobel, 1992). In the current study, we did not observe any differences between the ways in which racially heterogeneous groups engaged compared with racially homogeneous groups (Figure 6A). However, because the majority of students were white (Table 1) and many groups were homogenous with respect to race/ethnicity, there were likely not enough examples to observe potential benefits. Thus, we still strongly support promoting heterogeneous racial and ethnic groups when possible.

\section{Students' Natural Role Choices Are Not Necessarily Optimal}

Assigned roles, such as manager, presenter, recorder, and checker from POGIL, focus primarily on the format of discussion rather than the exchange of scientific ideas. Such organizational roles are clearly helpful, especially for long group discussions or long-term projects (Moog et al., 2006; Moog and Spencer, 2008). Students in the current study, who engaged in shorter discussions only four times over the semester, did not naturally adopt any of these roles except, rarely, the role of driver (most similar to the POGIL role of manager). This suggests that when students are unguided with regard to role selection, they are likely to engage in the quickest path to content understanding, preferentially taking on the role of analyst rather than roles that are focused on organization and/or equity of participation.

In addition to not taking on organizational roles, students often switched their roles from one discussion to the next: in fact, $40 \%$ switched roles in each discussion (Table 10). However, this malleability may have benefits. For example, students may change roles if they become more confident with content or more comfortable with the other students in the group, allowing them to shift from a more supplemental role such as generalist or minimalist to a more critical role like reasoner (Figure 8). Students may also change roles to compensate for a missing group member who is usually more vocal or dominant in the discussion (Figure 7), consciously or unconsciously reacting to the needs of the group. Similarly, a student may choose to shift from monopolizing the discussion to playing a minimalist role, thus allowing a different member of the group to use new skills. All of these shifts, even if unconscious, support the social cognitive theory of learning: that students generally do not act solely from an individualistic perspective, but rather are attuned to their group members and the social nature of learning. Nonetheless, given students' overall narrow preference for the role of analyst, instructors would be well served to help guide students into roles that promote deeper thinking. 
In addition, we suggest that some of the less commonly enacted roles of driver, knowledge facilitator, and questioner might be adopted by more students if they were aware of the value of such roles and more conscious of the social dynamics of their groups. A student who is aware of the benefits of cueing other members of the group to use reasoning (Knight et al., 2013) may be able to make such suggestions, stimulating argumentation within the group. Similarly, a knowledge facilitator, essentially acting as an instructor, can act to promote better discussion by engaging with others to help everyone explain their own ideas more fully (Webb et al., 2002; Beichner, 2007; Jensen and Lawson, 2011; Knight et al., 2015). Finally, the role of questioner can also stimulate more thorough understanding and exploration. By asking one another "why" or "how" they reached their conclusions, or even expressing statements of confusion, students can elicit responses from one another that stimulate a conceptual explanation and the use of reasoning.

\section{APPLICATIONS FOR INSTRUCTION}

We end with several suggestions that instructors can implement when students are engaged in group work, particularly if the group work is long term and intended to be generative.

\section{Promote Specific Behaviors and Roles to Fully Engage Students in the Social Aspects of Learning}

Providing examples and explanations of productive behaviors and specific roles may aid students in realizing there is value in working collaboratively. If students have an understanding of how to act as a reasoner, driver, knowledge facilitator, and questioner, and how these behaviors can create collaboration and interaction, they may be more likely to choose to engage in these roles. One way to promote this understanding would be to have students practice taking on a set of specific roles to accomplish a group goal and then discuss how each role helped to create a positive social dynamic as well as to construct a solution. This exercise could help students learn beneficial group behaviors without requiring them to step into preassigned roles. If students further practice switching roles and again discussing how their perspectives changed when they adopted different roles, they may feel more confident in adopting more than one beneficial role under unassigned conditions.

\section{Promote Argumentation}

Students need better tools to help them focus more on generating and exchanging reasoning while engaged in discussions, as they more naturally engage in explanations and analysis than in reasoning (Zeidler, 1997; Walker et al., 2012; Walker and Sampson, 2013; this study). One example from the literature that could be useful is argument-driven inquiry, a multistage instructional model for improving argumentation (Poock et al. 2007; Schroeder and Greenbowe, 2008; Walker and Sampson, 2013; Walker et al., 2012, 2019). Another less formal approach would be to provide instructions that explicitly prompt students to focus on exchanging reasoning in support of developing an argument. We suggest that a combination of verbal and written cues need to be given to students on a regular basis to establish the practice of reasoning. If students are not fully aware of how to connect evidence to claims or how to recognize whether others are using reasoning, they need to explicitly practice these skills and receive feedback from one another and instructors.
After such practice, reminders to use the principles of argumentation may be enough to promote collaboration and complete rationales to support their claims. Implementing such tools and others will require further study.

\section{ACKNOWLEDGMENTS}

Thank you to Kestrel Green for his assistance in coding recorded discussions, to Lisa Corwin for advice, to members of the Corwin and Knight labs for feedback, and to the students who participated in these studies. This work was funded by a grant from the National Science Foundation (DUE 1711348).

\section{REFERENCES}

American Association for the Advancement of Science. (2011). Vision and change in undergraduate biology education: A call to action. Washington, DC.

Asterhan, C. S. C., \& Schwartz, B. B. (2009). Argumentation and explanation in conceptual change: Indications from protocol analyses of peer-topeer dialog. Cognitive Science, 33(3), 374-400. https://doi.org/ 10.1111/j.1551-6709.2009.01017

Bandura, A. (1977). Self-efficacy: Toward a unifying theory of behavioral change. Psychological Review, 84(2), 191-215. https://doi.org/ 10.1037/0033-295X.84.2.191

Barber, S. J., Harris, C. B., \& Rajaram, S. (2015). Why two heads apart are better than two heads together: Multiple mechanisms underlie the collaborative inhibition effect in memory. Journal of Experimental Psychology: Learning, Memory, and Cognition, 41(2), 559-566. https://doi.org/ $10.1037 / x \operatorname{lm} 0000037$

Beichner, R. (2007). The Student-Centered Activities for Large Enrollment Undergraduate Programs (SCALE-UP) Project. Retrieved March 11, 2020, from Www.compadre.org/Repository/document/ServeFile.cfm?ID $=4517 \& \mathrm{Doc} \mid \mathrm{D}=183$

Berland, L. K., \& Reiser, B. J. (2009). Making sense of argumentation and explanation. Science Education, 93(1), 26-55. https://doi.org/10.1002/ sce. 20286

Blumen, H. M., Young, K. E., \& Rajaram, S. (2014). Optimizing group collaboration to improve later retention. Journal of Applied Research in Memory and Cognition, 3(4), 244-251. https://doi.org/10.1016/j.jarmac 2014.05.002

Boa, L., Cai, T., Koenig, K., Fang, K., Han, J., Wang, J., ... \& Wu, N. (2009) Learning and scientific reasoning. Science, 323(5914), 587-597. http:// doi.org/10.1126/science.1167740

Cavallo, A. (1996). Meaningful learning, reasoning ability, and students' understanding and problem solving of topics in genetics. Journal of Research in Science Teaching, 33(6), 625-656. https://doi.org/10.1002/ (SICI)1098-2736(199608)33:6<625::AID-TEA3>3.0.CO;2-Q

Cavallo, A. M. L., Potter, W. H., \& Rozman, M. (2004). Gender differences in learning constructs, shifts in learning constructs, and their relationship to course achievement in structured inquiry, yearlong college physics course for life science majors. School Science and Mathematics, 104(6). https://doi.org/10.1111/j.1949-8594.2004.tb18000.x

Chi, M. T.H. (2009). Active-constructive-interactive: A conceptual framework for differentiating learning activities. Topics in Cognitive Science, 1 73-105. http://doi.org/10.111/j.1756-8765.2008.01005.x

Chi, T. H., \& Wylie, R. (2014). The ICAP framework: Linking cognitive engagement to active learning outcomes. Educational Psychologist, 49(4), 219243. https://doi.org/10.1080/00461520.2014.965823

Coil, D., Wenderoth, M. P., Cunningham, M., \& Dirks, C. (2010). Teaching the process of science: Faculty perception and effective methodology. CBE-Life Sciences Education, 9, 524-535. https://doi.org/10.1187/ cbe.10-01-0005

DebBurman, S. (2002). Learning how scientists work: Experimental research projects to promote cell biology learning and scientific process skills. Cell Biology Education, 1, 154-172. https://doi.org/10.1187/cbe.02-07-0024

Dirks, C., \& Cunningham, M. (2006). Enhancing diversity in science: Is teaching science process skills the answer? Cell Biology Education, 5, 218226. https://doi.org/10.1187/cbe.02-07-0024] 
Driver, R., Newton, P., \& Osborne, J. (2000). Establishing the norms of scientific argumentation in classrooms. Science Education, 84(3), 287-313. https://doi.org/10.1002/(SICI)1098-237X(200005)84:3<287::AIDSCE1>3.0.CO;2-A

Eddy, S. L., Brownell, S. E., Thummaphan, P., Ming-Chih, L., \& Wenderoth, M. P. (2015). Caution, student experience may very: social identities impact a student's experience in peer discussion. CBE-Life Sciences Education, 14, 1-17. https://doi.org/10.1187/cbe.15-05-0108

Eddy, S. L., Brownell, S. E., \& Wenderoth, M. P. (2014). Gender gaps in achievement and participation in multiple introductory biology classrooms. CBE-Life Sciences Education, 13, 468-478. https://doi.org/10.1187/ cbe.13-10-0204

Erduran, S., Simon, S., \& Osborne, J. (2004). TAPing into argumentation: Developments in the application of Toulmin's argument pattern for studying science discourse. Science Education, 88, 915-933. https://doi .org/10.1002/sce.20012

Farrell, J. J., Moog, R. S., \& Spencer, J. N. (1999). A guided inquiry general chemistry course. Journal of Chemical Education, 76(4), 570-574. https://doi.org/10.1021/ed076p570

Felton, M., Garcia-Mila, M., Villarroel, C., \& Gilabert, S. (2015). Arguing collaboratively: Argumentative discourse types and their potential for knowledge building. British Journal of Education Psychology, 85(3), 372-386. https://doi.org/10.1111/bjep.12078

Gisev, N. G., Bell, J. S., \& Chen, T. F. (2013). Interrater agreement and interrater reliability: Key concepts, approaches, and application. Research in Social and Administrative Pharmacy, 9(3), 330-338

Howard, W. E., Johnson, L., \& Zgourides, G. D. (2002). The influence of ethnic diversity on leadership, group process, and performance: An examination of learning teams. Journal of Intercultural Relations, 26(1), 1-16. https://doi.org/10.1016/S0147-1767(01)00032-3

Jensen, J. L., \& Lawson, A. (2011). Effects of collaborative group composition and inquiry instruction on reasoning gains and achievements in undergraduate biology. CBE-Life Sciences Education, 10(1), 64-73. https:// doi.org/10.1187/cbe.10-07-0089

Johnson, D. W., \& Johnson, R. T. (1999). Making cooperative learning work. Theory into Practice, 38(2), 26-35. https://doi.org/10.1080/ 00405849909543834

Johnson, D. W., Johnson, R. T., \& Smith, K. A. (1991). Active learning: Cooperation in the college classroom. Edina, $\mathrm{MN}$ : Interaction.

Johnson, D. W., Johnson, R. T., \& Taylor, B. (1993). Impact of cooperative and individualistic learning on high-ability students' achievement, self-esteem, and social acceptance. Journal of Social Psychology, 133(6), 839844. https://doi.org/10.1080/00224545.1993.9713946

Johnson, J. L., \& Lawson, A. E. (1998). What are the relative effects of reasoning ability and prior knowledge on biology achievement in expository and inquiry classes? Journal of Research and Science Teaching, 24, 89-109. https:// doi.org/10.1002/(SICI)1098-2736(199801)35:1<89::AID-TEA6>3.0.CO;2-J.

Kanari, Z., \& Millar, R. (2004). Reasoning from data: How students collect and interpret data in science investigations. Journal of Research and Science Teaching, 41(7), 748-769. https://doi.org/10.1002/tea.20020

Kitchen, D., \& McDougall, D. (1999). Collaborative learning on the Internet. Journal of Educational Technology Systems, 27(3), 245-258. https://doi .org/10.2190/5H41-K8VU-NRFJ-PDYK

Kitchen, E., Bell, J. D., Reeve, S., Sudweeks, R. R., \& Bradshaw, W. S. (2003) Teaching cell biology in the large-enrollment classroom: Methods to promote analytical thinking and assessment of their effectiveness. Cell Biology Education, 2(3), 180-194. https://doi.org/10.1187/cbe.02-11-0055

Knight, J. K., Wise, S. B., Rentsch, J., \& Furtak, E. M. (2015). Cues matter: Learning assistants influence introductory biology student interactions during clicker-question discussion. CBE-Life Sciences Education, 14(4), 1-14. https://doi.org/10.1187/cbe.15-04-0093

Knight, J. K., Wise, S. B., \& Southard, K. M. (2013). Understanding clicker discussions: Student reasoning and the impact of instructional cues. $C B E-$ Life Sciences Education, 12(4), 645-654. https://doi.org/10.1187/cbe.13 $-05-0090$

Koslowski, B. (1996). Theory and Evidence: The development of scientific reasoning. Cambridge, MA: MIT Press.

Krejins, K., Kirschner, P. A., \& Jochems, J. (2003). Identifying the pitfalls for social interaction in computer supported collaborative learning environ- ments: Review. Computers in Human Behavior, 19(3), 335-353. https:// doi.org/10.1016/S0747-5632(02)00057-2

Kuhn, D. (1993). Science as argument: Implications for teaching and learning scientific thinking. Science Education, 77, 319-337. https://doi .org/10.1002/sce.3730770306

Leupen, S. M., Kephart, K. L., \& Hodges, L. C. (2020). Factors influencing quality of team discussion: Discourse analysis in an undergraduate teambased learning biology course. CBE-Life Sciences Education, 19(7), 113. https://doi.org/10.1187/cbe.19-06-0112

Lubben, F. (2009). Gauging students' untutored ability in argumentation about experimental data: A South African case study. International Journal of Science Education, 32, 2143-2166. https://doi.org/10.1080/ 09500690903331886

Marion, S. B., \& Thorley, C. (2016). A meta-analytic review of collaborative inhibition and post collaborative memory: Testing the predictions of the retrieval strategy disruption hypothesis. Psychological Bulletin, 142(11), 1141-1164. https://doi.org/10.1037/bul0000071

Maxwell, J. A. (2013). Qualitative research design: An interactive approach Thousand Oaks, CA: Sage.

McLeod, P. L., \& Lobel, S. A. (1992). The effects of ethnic diversity on idea generations in small groups. Academy of Management Best Paper Proceedings. Paper presented at the annual meeting of the Academy of Management, Las Vegas, 227-231.

McNeill, K. L., \& Krajcik, J. (2007). Middle school students' use of appropriate and inappropriate evidence in writing scientific explanations. In Lovett, M. \& Shah, P. (Eds.), Thinking with data (pp. 233-265). New York: Taylor \& Francis.

McNeill, K. L., \& Krajcik, J. (2008). Scientific explanations: Characterizing and evaluating the effects of teachers' instructional practices on student learning. Journal of Research in Science Teaching, 45(1), 53-78. https:// doi.org/10.1002/tea.20201

Moog, R. S., \& Spencer, J. N. (2008). Process oriented guided inquiry learning (POGIL) (p. 994). Washington, DC: ACS Symposium Series; American Chemical Society.

Moog, R. S., Spencer, J. N., \& Straumanis, A. R. (2006). Process oriented guided inquiry learning: POGIL and the POGIL Project. STEM Innovation and Dissemination: Improving Teaching and Learning in Science, Technology, Engineering and Mathematics, 17(4), 41-52

National Research Council (NRC). (2007). Taking science to school: Learning and teaching science in grades $\mathrm{K}-8$. Washington, DC: National Academics Press.

NRC. (2012). Discipline-based education research: Understanding and improving learning in undergraduate science and engineering. Washington, DC: National Academics Press.

Osborne, J. (2010). Arguing to learn in science: The role of collaborative, critical discourse. Science, 328, 463-466. https://doi.org/10.1126/ science.1183944.

Osborne, J. F., \& Patterson, A. (2011). Scientific argument and explanation: A necessary distinction? Science Education, 95(4), 627-638. https://doi. org/10.1002/sce.20438 Google Scholar

Patton, M. Q. (2009). Qualitative research and evaluation methods. Thousand Oaks, CA: Sage.

Paulus, T. M. (2005). Collaborative and cooperative approaches to online group work: The impact of task type. Distance Education, 26(1), 111-125. https://doi.org/10.1080/01587910500081343

Poock, J., Bruke, K., Greenbowe, T., \& Hand, B. (2007). Using the science writing heuristic in the general chemistry laboratory to improve students academic performance. Journal of Chemical Education, 84(8), 13711378. https://doi.org/10.1021/ed084p1371

Premo, J., Cavagnetto, A., Davis, W. B., \& Brickman, P. (2018). Promoting collaborative classrooms: The impacts of interdependent cooperative learning on undergraduate interactions and achievement. CBE-Life Sciences Education, 17(32), 1-16. https://doi.org/10.1187/cbe.17-08-0176

Prevost, L. B., \& Lemons, P. P. (2016). Step by step: Biology undergraduates problem-solving procedures during multiple-choice assessment CBE-Life Sciences Education, 15, 1-14. https://doi.org/10.1187/cbe.15 $-12-0255$

Repice, M. D., Sawyer, R. K., Hogrebe, M. C., Brown, P. L., Luesse, S. B., Bealy, D. J., \& Frey, R. (2016). Talking through the problems: A study on discourse 
in peer-led small groups. Chemistry Education Research and Practice, 17, 555-568. https://doi.org/10.1039/c5rp00154d

Saldana, J. (2015). The coding manual for qualitative researchers. Thousand Oaks, CA: Sage.

Sampson, V., Grooms, J., \& Walker, J. P. (2011). Argument-driven inquiry as a way to help students learn how to participate in scientific argumentation and craft written arguments: An exploratory study. Science Education, 95(2), 217-257.

Sandoval, W. A., \& Millwood, K. A. (2005). The quality of students' use of evidence in written scientific explanations. Cognition and Instruction, 23(1), 23-55. https://doi.org/ 10.1207/s1532690xci2301_2

Sandoval, W. A., \& Reiser, B. J. (2004). Explanation-driven inquiry: Integrating conceptual and epistemic scaffolds for scientific inquiry. Science Education, 88(3), 345-372. https://doi.org/10.1002/sce.10130

Sandoval, W. A., \& Reiser, B. J. (1997). Evolving explanations in high school biology. Paper presented at: Annual Meeting of the American Educational Research Association (Chicago, IL)

Schroeder, J. D., \& Greenbowe, T. J. (2008). Implementing POGIL in the lecture and the science writing heuristic in the laboratory-student perceptions and performance in undergraduate organic chemistry. Chemistry Education Research and Practice, 9(2), 149-156. https://doi.org/10.1039/B806231P

Simonson, S. R. (2019). POGIL: An introduction to process oriented guided inquiry learning for those who wish to empower learners. Sterling VA: Stylus Publishing.

Simonson, S. R., \& Shadle, S. E. (2013). Implementing process oriented guided inquiry learning (POGIL) in undergraduate biomechanics: Lessons learned by a novice. Journal of STEM Education: Innovations and Research, 14(1), 56-62.

Tanner, K., Chatman, L. S., \& Allen, D. (2003). Approaches to cell biology teaching: Cooperative learning in the science classroom-beyond students working in groups. Cell Biology Education, 2(1), 1-5. https://doi. org/10.1187/cbe.03-03-0010

Tolmie, A., \& Howe, C. (1993). Gender and dialogue in secondary school physics. Gender and Education, 5(2), 191-220.

Toulmin, S. E. (1958). The uses of argument. New York: Cambridge University Press.
Viera, A. J., \& Garrett, J. M. (2005). Understanding interobserver agreement: The kappa statistic. Family Medicine, 37(5), 360-363.

Vygotsky, L. S. (1978). Mind in society: The development of higher psychological processes. Cole, M., John-Steiner, V., Scribner, S., \& Souberman, E. (Eds.). Cambridge, MA: Harvard University Press.

Walker, J. P., \& Sampson, V. (2013). Learning to argue and arguing to learn: Argument-driven inquiry as a way to help undergraduate chemistry students learn how to construct arguments and engage in argumentation during a laboratory course. Journal of Research and Science Teaching, 50(5), 561-596. https://doi.org/10.1002/tea.21082

Walker, J. P., Sampson, V., \& Zimmerman, C. (2012). Argument-driven inquiry: an introduction to a new instructional model for use in undergraduate chemistry labs: The impact on students' conceptual understanding, argument skills, and attitudes in science. Journal of College Science Teaching, 41(4), 74-81. https://doi.org/10.1021/ed100622h

Walker, J. P., Van Duzor, A. G., \& Lower, M. A. (2019). Facilitating argumentation in the laboratory: The challenges of claim change and justification by theory. Journal of Chemical Education, 96, 435-444. https://doi .org/10.1021/acs.jchemed.8b00745

Webb, N., Nemer, K., \& Zuniga, S. (2002). Short circuits or superconductors? Effects of group composition on high-achieving students' science assessment performance. American Educational Research Journal, 39(4), 943-989. https://doi.org/10.3102/00028312039004943

Weldon, M. S., \& Bellinger, K. D. (1997). Collective memory: Collaborative and individual processes in remembering. Journal of Experimental Psychology: Learning, Memory, and Cognition, 23(5), 1160-1175. https://doi .org/10.1037/0278-7393.23.5.1160

Zeidler, D. L. (1997). The central role of fallacious thinking in science education. Science Education, 81(4), 483-496. https://doi.org/10.1002/ (SICI)1098-237X(199707)81:4<483::AID-SCE7>3.0.CO;2-8

Zembal-Saul, C., McNeill, K. L., \& Hershberger, K. (2012). What's your evidence? Engaging $\mathrm{K}-5$ students in constructing explanations in science. Boston: Pearson Education.

Zohar, A., \& Nemet, F. (2002). Fostering students' knowledge and argumentation skills through dilemmas in human genetics. Journal of Research and Science Teaching, 39, 35-62. https://doi.org/10.1002/tea.10008 